\title{
Protease Inhibitors in Wild Relatives of Pigeonpea against the Cotton Bollworm/Legume Pod Borer, Helicoverpa armigera
}

\author{
Vinod D. Parde ${ }^{1,2}$, Hari C. Sharma ${ }^{1 *}$, Manvendra S. Kachole ${ }^{2}$ \\ ${ }^{1}$ International Crops Research Institute for the Semi-Arid Tropics, Patancheru, India; ${ }^{2}$ Department of Biochemistry, Dr. Babasaheb \\ Ambedkar Marathwada University, Aurangabad, India. \\ Email: "h.sharma@cgiar.org
}

Received February $23^{\text {rd }}, 2012$; revised March $7^{\text {th }}, 2012$; accepted March $20^{\text {th }}, 2012$

\begin{abstract}
Cotton bollworm/legume pod borer, Helicoverpa armigera is one of the most damaging pests worldwide. Because of the difficulties associated with chemical control of this pest, emphasis has been placed on developing transgenic plants with resistance to $H$. armigera. Since toxin genes from the bacterium, Bacillus thuringiensis (Bt) have been deployed on a large scale, there is need to scout for alternate genes which could be deployed alone or in combination with the $B t$ genes for pest management. Therefore, we evaluated the wild relatives of pigeonpea, which have shown high levels of resistance to this pest, for the protease inhibitors (PIs) under in vivo and in vitro inhibitions. Accessions belonging to Cajanus albicans, C. cajanifolius, C. sericeus, Flemingia bracteata, and Rhynchosia bracteata showed complete inhibition of H. armigera gut proteinases (HaGPs). Some of the C. scarabaeoides accessions (ICPW 116, 152, 278 and 280) exhibited partial inhibition at low concentrations of the PIs. All accessions of wild relatives of pigeonpea showed high to moderate level of inhibition at $\mathrm{pH}$ 7.8. Cultivated pigeonpea, ICPL 87 exhibited monomorphism in terms of trypsin inhibitor (TI) and chymotrypsin inhibitor (CTI) isoforms, contrary to the diverse inhibitory profiles of wild pigeonpeas. Cajanus albicans, C. platycarpus, C. scarabaeoides, and R. bracteata showed more number of TI and CTI bands than the cultivated pigeonpea. Protease inhibitor isoforms of wild relatives of pigeonpea showed significant variation in number, band pattern, and protein specificities towards trypsin, chymotrypsin, and H. armigera gut proteinases (HaGPs) as compared to the cultivated pigeonpea. The PIs from the wild relatives of pigeonpea showed considerable potential against the HaGPs, and could be considered as potential candidates for use in genetic transformation of crops for pest management, including $H$. armigera.
\end{abstract}

Keywords: Wild Relatives; Pigeonpea; Protease Inhibitors; Helicoverpa armigera; Transgenic Plants; Pest Management

\section{Introduction}

Pigeonpea [Cajanus cajan (L.) Millisp.] is a multipurpose grain legume grown by the resource poor farmers in the semi-arid tropics and subtropics. India produces more than $80 \%$ of the total production of pigeonpea [1]. It occupies an important position in human diet as a protein source, especially in the vegetarian population [2]. The most important constraints of pigeonpea production include Fusarium wilt, sterility mosaic disease, and the insect pests such as pod borer, Helicoverpa armigera (Hub.), spotted pod borer, Maruca vitrata (Geyer), pod fly, Melanagromyza obtusa (Malloch), pod bug, Clavigralla spp., Lima bean pod borer, Etiella zinckenella (Tr.), and the bruchids, Callosobruchus chinensis (F.).

"Corresponding author.
Amongst these, $H$. armigera is the most damaging pest of grain legumes, including pigeonpea, and causes losses valued over US $\$ 325$ million annually $[3,4]$. Chemical control with insecticides is costly, and it has developed high levels of resistance to conventional insecticides [5]. Therefore, there is need to focus our attention on alternative methods of pest control. It is in this context that host plant resistance can play an important role in minimizing the extent of losses due to this pest. However, the levels of resistance to this pest in the cultivated germplasm are low to moderate [6], but the wild relatives of pigeonpea have shown high levels of resistance to this pest [7-9]. Transfer of insect resistance genes from the wild into cultivated species is a long term process, but certain genes that control the production and accumulation of compounds that affect the survival and development of 
insects can be utilized more effectively through gene cloning, and insertion into a desirable variety or hybrid released for cultivation by the farmers. Protease inhibitors are produced in the plants in response to biotic or abiotic stress and protect the plant against herbivores, including insect pests [10]. Their potential in the development of insect resistant plants using recombinant DNA technology has also been demonstrated [8].

Pigeonpea seeds contain proteinaceous inhibitors (PIs) of trypsin, chymotrypsin, and amylases [11-13] as well as phytolectins, and secondary metabolites [14-16], which serve as a defense mechanism against the herbivores. Pigeonpea PIs are Kunitz type PIs, having inhibitory activity against trypsin and chymotrypsin [16,17]. However, $H$. armigera has developed the ability to overcome the effect of host plant PIs either by producing a different suite of proteases or overproduction of certain proteases to overcome the adverse effects of host plant PIs [18]. However, PIs from the non-host plants have been found to be more effective against this pest [19]. It is likely the PIs from the wild relatives of pigeonpea, that have shown high levels of resistance to this pest, will be more effective as inhibitors of proteases in the insect gut. Therefore, the present studies were undertaken to assess the potential of PIs from the wild relatives of pigeonpea to identify species/accession with high PI activity for possible use in genetic transformation of crops for resistance to H. armigera.

\section{Materials and Methods}

\subsection{Seeds of Wild Relatives of Pigeonpea}

Twenty-nine accessions (germplasm lines kept in the genebank) belonging to 13 species (Cajanus scarabaeoides, C. cajanifolius, C. sericeus, C. albicans, C. acutifolius, C. lineatus, C. platycarpus, Rhynchosia bracteata, $R$. aurea, Dunbaria ferruginea, Flemingia bracteata, $F$. stricta, and Paracalyx scariosa) of wild relatives of pigeonpea were evaluated for their PI activity against the larvae of pod borer, H. armigera, along with two genotypes of cultivated pigeonpea, Cajanus cajan (ICPL 87susceptible check, and ICPL 332-resistant check) $[8,9]$. The test material was planted under field conditions at the International Crops Research Institute for the SemiArid Tropics (ICRISAT), Patancheru, Andhra Pradesh, India. The seeds were sown on ridges $75 \mathrm{~cm}$ apart, and thinned to a spacing of $30 \mathrm{~cm}$ between the plants at 15 days after seedling emergence. Standard agronomic practices were followed for raising the crop (basal fertilizer$\mathrm{N}: \mathrm{P}: \mathrm{K}: 100: 60: 40 \mathrm{~kg} \cdot \mathrm{ha}^{-1}$ ). A fungicide spray (metalaxyl (a) $1.0 \mathrm{~kg} \cdot a i \cdot \mathrm{ha}^{-1}$ ) was applied to control Fusarium wilt during the seedling stage. The crop was raised under rainfed conditions between June to October, but irrigated at monthly intervals between November to February during the postrainy period. Wooden pegs $(1.5 \mathrm{~m}$ high) were used to provide support for C. scarabaeoides and $C$. platycarpus accessions, which have a creeping habit. The pods were collected from different accessions during December-January, thrashed, and the seeds used for assessing the PI activity under laboratory conditions.

\subsection{Extraction of Seed Proteins}

Mature seeds were washed with water, dried, and ground to a fine powder in a pestle and mortar. The seed powder was defatted with hexane and depigmented with acetone. Defatted seed powder was suspended in six volumes of distilled water containing $1 \% \mathrm{PVP}$ and kept at $15^{\circ} \mathrm{C}$ for $12 \mathrm{~h}$ for extraction of seed proteins. The suspension was centrifuged at $10,000 \mathrm{rpm}$ for $30 \mathrm{~min}$ at $4^{\circ} \mathrm{C}$, and the supernatant was used for analysis of inhibitors of bovine trypsin and chymotrypsin. Protein content in the seed extracts was estimated by the method of Lowry et al. (1951) [20] using bovine serum albumin as a standard.

\subsection{Detection of Protease Inhibitors by Dot-Blot Method}

We used X-ray film method for the estimating serine protease inhibitor activity [21]. Trypsin and chymotrypsin solutions were prepared in $0.1 \mathrm{M}$ Tris- $\mathrm{HCl}$ buffer, $\mathrm{pH}$ 7.8 , to obtain a final concentration of $0.1 \mathrm{mg} \cdot \mathrm{ml}^{-1}$. Three varying concentrations of the enzyme and inhibitor 3:1, $1: 1$, and $1: 3(\mathrm{v} / \mathrm{v})$, were prepared. The volume of the reaction mixture was adjusted with Tris-HCl buffer for trypsin and chymotrypsin, and glycine- $\mathrm{NaOH}$ buffer for H. armigera gut proteinases (HaGPs). The final volume was made upto $20 \mu \mathrm{l}$, and then spotted onto a strip of $\mathrm{X}$-ray film. Spots were incubated for $20 \mathrm{~min}$ on X-ray film depending on the extent of gelatin hydrolysis. The film was washed with warm water. When the inhibitor is present, the trypsin/chymotrypsin did not degrade the gelatin on the X-ray film. When the inhibitor was absent, a clear zone formed at the site of sample application on the X-ray film. The reverse side of the film was cleared with trypsin/chymotrypsin, and the film scanned.

\subsection{Proteinase Assay}

The residual proteinase activity was estimated using casein as a substrate [22]. The proteinase-inhibitor mixture was added to $0.5 \mathrm{ml}$ of $0.5 \%$ casein (in $0.2 \mathrm{M}$ glycine$\mathrm{NaOH}, \mathrm{pH} 10.0$ ) and kept at $37^{\circ} \mathrm{C}$ for $20 \mathrm{~min}$. The reaction was terminated by the addition of $750 \mu \mathrm{L}$ of $5 \%$ trichloroacetic acid. After centrifugation at 10,000 rpm for $10 \mathrm{~min}$, absorbance of the supernatant was checked at $280 \mathrm{~nm}$. For every assay, suitable controls were co-in- 
cubated with the test samples. Trypsin-like activities were estimated using chromogenic substrate, benzoylarginyl $p$-nitroanilide (BApNA) [23]. For trypsin assay, diluted enzyme $(150 \mu \mathrm{L})$ was added to $1 \mathrm{~mL}$ of $1 \mathrm{mM}$ BApNA (in $0.2 \mathrm{M}$ glycine- $\mathrm{NaOH}, \mathrm{pH} 10.0$ ) and incubated at $37^{\circ} \mathrm{C}$ for $10 \mathrm{~min}$. The reaction was terminated by the addition of $200 \mu \mathrm{L}$ of $30 \%$ acetic acid, and the absorbance measured at $410 \mathrm{~nm}$. One proteinase unit was defined as the amount of enzyme that increased absorbance by 1 OD under the given assay conditions.

\subsection{Inhibition Potential of Wild Pigeonpea PIs against Gut the Proteinases of $\boldsymbol{H}$. armigera at Different $\mathrm{pH}$ and Temperature Conditions}

Inhibition potential of different PIs against gut proteinase activity of $H$. armigera was determined using BApNA as a substrate. Activity assays were performed at $\mathrm{pH} 7.8$ and $\mathrm{pH}$ 10.0. Double concentration of the gut extract was required to obtain equivalent units of BApNAase activity at $\mathrm{pH} 7.8$ than at $\mathrm{pH}$ 10.0. Five different concentrations of inhibitors were used to assess the potential of inhibitor for inhibiting HaGP. In vitro stability of wild pigeonpea PIs against $\mathrm{HaGP}$ was determined by pre-incubating the inhibitors with $\mathrm{HaGP}$ for $30 \mathrm{~min}$, and for $3 \mathrm{~h}$ at $37^{\circ} \mathrm{C}$, and then assayed for their inhibitory activity towards HaGP.

\subsection{Effect of Synthetic Protease Inhibitors on Gut Proteinase Activity}

Nine chemical inhibitors viz., antipain, leupeptin, pefabloc, aprotinin, chymostatin, E-64, pepstatin, EDTA, and soybean trypsin inhibitor were used in the range of $1.8 \mu \mathrm{M}$ to $10 \mathrm{mM}$ concentrations for maximum inhibition of the enzyme in assays. Inhibitors were dissolved in water (antipain, pefabloc, EDTA, soybean trypsin inhibitor, and aprotinin) or DMSO (chymostatin) or methanol (pepstatin) or water/ethanol (1:1) (E-64) as per the manufacturer's instructions. For the inhibitor assay, suitable volume of seed extract of chemical inhibitor required for maximum inhibition of the enzyme was added to the gut proteinase extract and incubated at room temperature $\left(27^{\circ} \mathrm{C}\right)$ for $15 \mathrm{~min}$. The residual proteinase activity was then estimated using casein as a substrate [22].

\subsection{Electrophoretic Analysis of Wild Pigeonpea PIs}

Pigeonpea seed extracts were analyzed by non-denaturing acidic and basic, and denaturing sodium dodecyl sulfate (SDS) polyacrylamide gel electrophoresis (PAGE) in a vertical slab gel electrophoresis system. Acidic gel electrophoresis was carried out in $10 \%$ polyacrylamide gel using a cathodic discontinuous buffer system. Basic gel electrophoresis was carried out in $10 \%$ or $12 \%$ polyacrylamide gel by using Davis buffer system.

After electrophoresis, non-SDS gel was placed in 0.1 $\mathrm{M}$ Tris- $\mathrm{HCl}(\mathrm{pH}$ 7.8) for $5-10 \mathrm{~min}$ for equilibration. The SDS-gel was washed three times $(30 \mathrm{~min}$ each) with $2.5 \%$ Triton $\mathrm{X}-100$ in $0.1 \mathrm{M}$ Tris- $\mathrm{HCl}(\mathrm{pH} 7.8)$ for a few minutes. After equilibration, the gel placed in $0.1 \mathrm{mg} / \mathrm{ml}$ trypsin or in chymotrypsin in $0.1 \mathrm{M}$ Tris- $\mathrm{HCl}(\mathrm{pH} 7.8)$ for $5-10 \mathrm{~min}$, rinsed briefly in the Tris- $\mathrm{HCl}$ buffer $(\mathrm{pH}$ 7.8), and placed on an exposed undeveloped X-ray film, or exposed and developed photographic paper. The gel and the film were placed in a tray and incubated at $37^{\circ} \mathrm{C}$ in a water bath. The appearance of inhibitor bands on $\mathrm{X}$-ray film was monitored visually. The X-ray film was then rinsed under tap water or placed in a water tray and shaken gently to remove hydrolyzed gelatin. The gel was rinsed in $0.1 \mathrm{M}$ Tris- $\mathrm{HCl}(\mathrm{pH} 7.8)$ briefly, and placed on another film with second side of the gel in contact with the film. For comparison of sensitivity of detection of inhibitory activity using film, a gel containing duplicate samples was cut into two pieces after electrophoresis and processed under similar conditions.

\subsection{Statistical Analysis}

The data were subjected to analysis of variance to compute the standard deviations from the mean for each assay.

\section{Results and Discussion}

At three concentrations of HaGPs and the inhibitor (3:1, 1:1 and 1:3), 18 accessions (ICPW nos 13, 14, 28, 29, $160,68,83,90,94,125,130,137,141,281,192,202$ and 214, and ICPL332) resulted in total inhibition of HaGP (Table 1). Accessions belonging to C. albicans, $C$. cajanifolius, C. sericeus, F. bracteata, and $R$. bracteata showed complete inhibition of HaGPs. Some of the accessions belonging to C. scarabaeoides (ICPW nos 116, 152, 278 and 280) also exhibited partial inhibition at low concentrations of PIs (3:1; enzyme:inhibitor).

Maximum HaGP inhibition by PIs of pigeonpea and its wild relatives was observed when different concentrations of protein $(10-550 \mu \mathrm{g})$ were independently tested against the HaGP. Among the cultivated pigeonpea cultivars, the inhibition of HaGP was greater in the H. armigera-resistant cultivar-ICPL $332(65 \%)$ than in the susceptible check, ICPL 87 (38\%) (Table 2). Among the wild relatives of pigeonpea, highest inhibition of HaGP (85\%) was observed in C. albicans (ICPW 14) and $R$. bracteata (ICPW 214), and lowest (63\%) in C. cajanifolius (ICPW 28) (Table 2). Cajanus scarabaeoides accessions exhibited $65 \%$ to $74 \%$ inhibition of HaGP. Low inhibition potential of HaGPs explained the susceptibility 
Table 1. In vitro screening of Helicoverpa armigera gut proteases inhibition using spot test.

\begin{tabular}{|c|c|c|c|c|}
\hline \multirow[t]{2}{*}{ Species } & \multirow[t]{2}{*}{ Accession } & \multicolumn{3}{|c|}{$\begin{array}{l}\text { Concentration of } \\
\text { HaGP:Seed extract }\end{array}$} \\
\hline & & $3: 1$ & $1: 1$ & $1: 3$ \\
\hline \multirow[t]{2}{*}{ Cajanus acutifolius } & ICPW 1 & $\mathrm{P}$ & $\mathrm{T}$ & $\mathrm{T}$ \\
\hline & ICPW 2 & $\mathrm{P}$ & $\mathrm{T}$ & $\mathrm{T}$ \\
\hline \multirow[t]{2}{*}{ C. albicans } & ICPW 13 & $\mathrm{~T}$ & $\mathrm{~T}$ & $\mathrm{~T}$ \\
\hline & ICPW 14 & $\mathrm{~T}$ & $\mathrm{~T}$ & $\mathrm{~T}$ \\
\hline \multirow[t]{2}{*}{ C. cajanifolius } & ICPW 28 & $\mathrm{~T}$ & $\mathrm{~T}$ & $\mathrm{~T}$ \\
\hline & ICPW 29 & $\mathrm{~T}$ & $\mathrm{~T}$ & $\mathrm{~T}$ \\
\hline C. lineatus & ICPW 40 & $\mathrm{~N}$ & $P$ & $\mathrm{~T}$ \\
\hline \multirow[t]{2}{*}{ C. sericeus } & ICPW 159 & $\mathrm{P}$ & $\mathrm{P}$ & $\mathrm{T}$ \\
\hline & ICPW 160 & $\mathrm{~T}$ & $\mathrm{~T}$ & $\mathrm{~T}$ \\
\hline C. platycarpus & ICPW 68 & $\mathrm{~T}$ & $\mathrm{~T}$ & $\mathrm{~T}$ \\
\hline \multirow[t]{12}{*}{ C. scarabaeoides } & ICPW 83 & $\mathrm{~T}$ & $\mathrm{~T}$ & $\mathrm{~T}$ \\
\hline & ICPW 90 & $\mathrm{~T}$ & $\mathrm{~T}$ & $\mathrm{~T}$ \\
\hline & ICPW 94 & $\mathrm{~T}$ & $\mathrm{~T}$ & $\mathrm{~T}$ \\
\hline & ICPW 116 & $\mathrm{P}$ & $\mathrm{T}$ & $\mathrm{T}$ \\
\hline & ICPW 125 & $\mathrm{~T}$ & $\mathrm{~T}$ & $\mathrm{~T}$ \\
\hline & ICPW 130 & $\mathrm{~T}$ & $\mathrm{~T}$ & $\mathrm{~T}$ \\
\hline & ICPW 137 & $\mathrm{~T}$ & $\mathrm{~T}$ & $\mathrm{~T}$ \\
\hline & ICPW 141 & $\mathrm{~T}$ & $\mathrm{~T}$ & $\mathrm{~T}$ \\
\hline & ICPW 152 & $\mathrm{P}$ & $\mathrm{T}$ & $\mathrm{T}$ \\
\hline & ICPW 278 & $\mathrm{P}$ & $\mathrm{T}$ & $\mathrm{T}$ \\
\hline & ICPW 280 & $\mathrm{P}$ & $\mathrm{T}$ & $\mathrm{T}$ \\
\hline & ICPW 281 & $\mathrm{~T}$ & $\mathrm{~T}$ & $\mathrm{~T}$ \\
\hline Flemingia bracteata & ICPW 192 & $\mathrm{~T}$ & $\mathrm{~T}$ & $\mathrm{~T}$ \\
\hline F. stricta & ICPW 202 & $\mathrm{~T}$ & $\mathrm{~T}$ & $\mathrm{~T}$ \\
\hline Paracalyx scariosa & ICPW 207 & $\mathrm{P}$ & $\mathrm{T}$ & $\mathrm{T}$ \\
\hline Rhynchosia bracteata & ICPW 214 & $\mathrm{~T}$ & $\mathrm{~T}$ & $\mathrm{~T}$ \\
\hline R. aurea & ICPW 210 & $\mathrm{P}$ & $\mathrm{T}$ & $\mathrm{T}$ \\
\hline \multirow[t]{2}{*}{ C. cajan } & ICPL 87 & $\mathrm{~N}$ & $\mathrm{P}$ & $\mathrm{T}$ \\
\hline & ICPL 332 & $\mathrm{~T}$ & $\mathrm{~T}$ & $\mathrm{~T}$ \\
\hline
\end{tabular}

$\mathrm{N}=$ No inhibition. The HaGPs activity is not inhibited by the protease inhibitors. $\mathrm{P}=$ Partial inhibition. The HaGPs activity is moderately inhibited due to some protease inhibitors belonging to serine class, but are not present in enough concentrations to inhibit the total activity. $\mathrm{T}=$ Total inhibition. The HaGPs activity is totally inhibited by the protease inhibitors.

of pigeonpea to $H$. armigera larvae. Pigeonpea PIs and amylase inhibitors accumulate during seed development, and host defense is inadequate during the early stages of grain development [24,25]. Insects also inactivate host plant defenses by expressing inhibitor resistant or inhibitor degrading proteinases [12,26-30]. Therefore, screening of non-host plants and/or wild relatives for identification of strong insect gut PIs is a prerequisite for applica- tion of PI-based strategy for developing insect-resistant transgenic plants $[12,19,31]$. Screening of several wild relatives of chickpea did not lead to the identification of strong inhibitors of HaGP [29] as H. armigera is a polyphagous pest. This certainly makes it difficult to find potential PIs for HaGP, even from the non-host plants. In this connection, the wild relatives of pigeonpea could serve as good sources of powerful HaGP inhibitors.

To examine the specificity of HaGP of $H$. armigera larvae feeding on chickpea and pigeonpea, the gut extracts were also assayed for inhibition by chemical inhibitors of different specificities (Table 3). The HaGPs' of larvae fed on chickpea were inhibited strongly by serine PIs, antipain (83\%), leupeptin (84\%), pefabloc (85\%), aprotinin $(65 \%)$, soybean trypsin inhibitor $(54 \%)$, and chymostatin (50\%), but not by E-64, pepstatin, and EDTA, suggesting the absence of cysteine proteinases, aspartic proteinases, and metalloproteinases, respectively. Similarly, the HaGPs' of the larvae fed on pigeonpea showed inhibition of serine PIs, antipain (65\%), leupeptin (75\%), pefabloc $(92 \%)$, aprotinin $(87 \%)$, and soybean trypsin inhibitor (72\%) (Table 3). However, the proteinase activity was significantly inhibited by chymostatin $(80 \%)$ and EDTA (58\%), and to a lesser extent by E-64 (28\%) and pepstatin $(28 \%)$, indicating the existence of proteinases with highly complex specificities in $H$. armigera fed on pigeonpea.

The gut proteinase complement of $H$. armigera exhibits predominately trypsin-like proteinase activity [32]. Although, the insect trypsins are similar to bovine trypsin in their catalytic properties, they differ in their $\mathrm{pH}$ optima $[32,33]$, and sensitivity towards inhibitors of plant or chemical origin $[34,35]$. The differences in the extent of inhibition by the five serine PIs towards HaGP of larvae fed on two different hosts pointed to different specificities in the trypsin-like activities in the $H$. armigera gut. Bown et al. (1997) [26] reported that although the serine PIs antipain, leupeptin, and benzamidine inhibited 98\% of HaGP activity, a general serine proteinase inhibitor PMSF inhibited only $28 \%$ of HaGP activity in larvae reared on artificial diet. Further, presence of at least 28 genes of trypsin- and chymotrypsin-like proteinases in $H$. armigera with 90\% homology and minor differences near the active sites of these proteinases was shown by Bown et al. (1997) [26]. Mazumdar-Leighton et al. (2000) [36] reported the presence of two transcripts for trypsinlike proteinases in $H$. armigera. Moderate to high level of chymotrypsin-like activity was detected in the larvae fed on pigeonpea, whereas very low activity was detected in larvae fed on chickpea. The gut composition of larvae fed on pigeonpea contrasted with that of $H$. armigera larvae fed on chickpea. Helicoverpa armigera fed on pigeonpea revealed the presence of metalloproteinase, 
Table 2. Protein content in the mature seeds, maximum HGP inhibition, in vitro inhibition, and percentage inhibition at different $\mathrm{pH}$ levels in wild relatives of pigeonpea against the pod borer, Helicoverpa armigera.

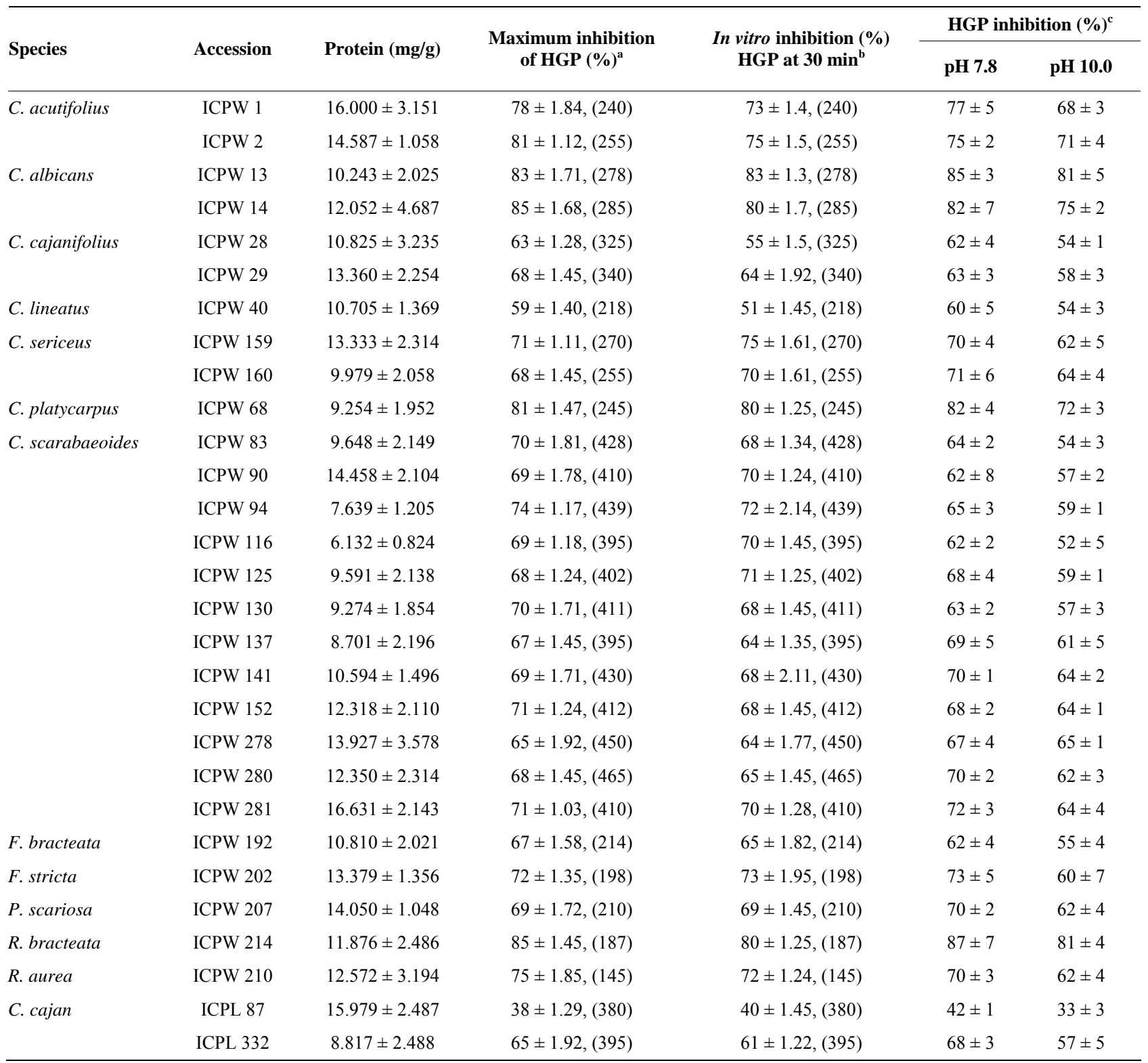

The values are average of three replicates \pm SD. ${ }^{\mathrm{a}}$ The $\%$ inhibition indicated in the table is the highest possible inhibition, which causes @ $100 \%$ inhibition of trypsin with respective seed extract. The values in the parenthesis are protein content $(\mu \mathrm{g})$ of the seed extract used to obtain maximum inhibition of HGP. ${ }^{\mathrm{b}}$ In vitro stability of wild pigeonpea protease inhibitors against HGP. Inhibitors were pre-incubated with $\mathrm{HGP}$ for $30 \mathrm{~min}$ at $37^{\circ} \mathrm{C}$. The values in the parenthesis are protein content $(\mu \mathrm{g})$ of the seed extract used to obtain maximum inhibition of HGP. ${ }^{\mathrm{c}}$ Activity assays were performed at $\mathrm{pH} 7.8$ and 10.0 . Double concentration of gut extract was required to obtain equivalent units of BApNAase activity at $\mathrm{pH} 7.8$ than at $\mathrm{pH} 10.0$. Five concentrations of inhibitor extract were used to assess the potential of inhibitor for inhibiting HGP activity.

and a lower percentage of aspartic and cysteine proteinases, which were absent in the gut of larvae fed on chickpea.

When, HaGP of second- and fifth-instars of $H$. armigera fed on artificial diet were assessed for their inhibition by chemical inhibitors, HaGP of second-instars showed $55 \%$ to $75 \%$ inhibition by serine PIs such as leupeptin, pefabloc, aprotinin, and soybean trypsin inhibi- tor, with the exception of antipain, which inhibited only $45 \%$ of HaGP activity (Table 4). Interestingly, substantial inhibition was shown by pepstatin (42\%), E-64 (38\%), EDTA (32\%), and chymostatin (30\%), indicating the presence of specificity of other than serine proteinases in the second-instars. HaGPs of fifth-instars showed inhibition by all the serine PIs viz., antipain (68\%), leupeptin (71\%), pefabloc (87\%), aprotinin $(52 \%)$, 
Table 3. Effect of chemical inhibitors on gut proteinase activity of $\boldsymbol{H}$. armigera fed on artificial diet. Inhibition of gut proteinase activity was measured using casein as a substrate.

\begin{tabular}{|c|c|c|c|c|}
\hline \multirow[t]{2}{*}{$\begin{array}{l}\text { Chemical } \\
\text { inhibitor }\end{array}$} & \multirow[t]{2}{*}{$\begin{array}{l}\text { Specificity of } \\
\text { the inhibitor }\end{array}$} & \multirow[t]{2}{*}{$\begin{array}{c}\text { Effective } \\
\text { concentration }\end{array}$} & \multicolumn{2}{|c|}{$\begin{array}{l}\text { Inhibition of gut proteinase activity } \\
\text { of larvae fed on artificial diet (\%) }\end{array}$} \\
\hline & & & Chickpea & Pigeonpea \\
\hline \multirow[t]{2}{*}{ Antipain } & Serine & $275 \mu \mathrm{M}$ & $83 \pm 4$ & $65 \pm 2$ \\
\hline & Proteinases & & & \\
\hline \multirow[t]{2}{*}{ Leupeptin } & Serine & $25 \mu \mathrm{M}$ & $84 \pm 10$ & $75 \pm 8$ \\
\hline & Proteinases & & & \\
\hline \multirow[t]{2}{*}{ Pefabloc } & Serine & $10 \mathrm{mM}$ & $85 \pm 5$ & $92 \pm 8$ \\
\hline & Proteinases & & & \\
\hline \multirow[t]{2}{*}{ Aprotinin } & Serine & $1.8 \mu \mathrm{M}$ & $65 \pm 10$ & $87 \pm 8$ \\
\hline & Proteinases & & & \\
\hline Soybean trypsin & Trypsin & $1 \mathrm{mM}$ & $54 \pm 8$ & $72 \pm 8$ \\
\hline \multicolumn{5}{|l|}{ Inhibitor } \\
\hline Chymostatin & Chymotrypsin & $280 \mu \mathrm{M}$ & $50 \pm 10$ & $80 \pm 8$ \\
\hline \multirow[t]{2}{*}{ E-64 } & Cysteine & $150 \mu \mathrm{M}$ & 0 & $28 \pm 10$ \\
\hline & Proteinases & & & \\
\hline \multirow[t]{2}{*}{ Pepstatin } & Aspartic & $10 \mu \mathrm{M}$ & 0 & $28 \pm 10$ \\
\hline & Proteinases & & & \\
\hline EDTA-Na2 & Metallo-Proteinases & $1 \mathrm{mM}$ & 0 & $58 \pm 10$ \\
\hline
\end{tabular}

*The values are average of three replicates $\pm \mathrm{SE}$.

Table 4. Effect of chemical inhibitors on gut proteinase activities of second and fifth instar of $\boldsymbol{H}$. armigera larvae fed on artificial diet. Inhibition of gut proteinase activity was measured using casein as a substrate.

\begin{tabular}{|c|c|c|c|}
\hline $\begin{array}{l}\text { Chemical } \\
\text { inhibitor }\end{array}$ & $\begin{array}{l}\text { Specificity of } \\
\text { the inhibitor }\end{array}$ & $\begin{array}{c}\text { Effective } \\
\text { concentration }\end{array}$ & $\begin{array}{l}\text { Inhibition of } \\
\text { HGP }(\%)^{*} \text { of }\end{array}$ \\
\hline & & & $\begin{array}{c}\text { Second Fifth } \\
\text { instar instar }\end{array}$ \\
\hline \multirow[t]{2}{*}{ Antipain } & Serine & $275 \mu \mathrm{M}$ & $45 \pm 568 \pm 10$ \\
\hline & Proteinases & & \\
\hline \multirow[t]{2}{*}{ Leupeptin } & Serine & $25 \mu \mathrm{M}$ & $75 \pm 8 \quad 71 \pm 3$ \\
\hline & Proteinases & & \\
\hline \multirow[t]{2}{*}{ Pefabloc } & Serine & $10 \mathrm{mM}$ & $70 \pm 2 \quad 87 \pm 7$ \\
\hline & Proteinases & & \\
\hline \multirow[t]{2}{*}{ Aprotinin } & Serine & $1.8 \mu \mathrm{M}$ & $59 \pm 1052 \pm 7$ \\
\hline & Proteinases & & \\
\hline Soybean trypsin & Trypsin & $1 \mathrm{mM}$ & $55 \pm 8 \quad 64 \pm 7$ \\
\hline \multicolumn{4}{|l|}{ Inhibitor } \\
\hline Chymostatin & Chymotrypsin & $280 \mu \mathrm{M}$ & $30 \pm 2 \quad 55 \pm 3$ \\
\hline \multirow[t]{2}{*}{ E-64 } & Cysteine & $150 \mu \mathrm{M}$ & $38 \pm 7 \quad 20 \pm 4$ \\
\hline & Proteinases & & \\
\hline \multirow[t]{2}{*}{ Pepstatin } & Aspartic & $10 \mu \mathrm{M}$ & $42 \pm 5 \quad 38 \pm 4$ \\
\hline & Proteinases & & \\
\hline EDTA-Na2 & Metallo-Proteinases & $1 \mathrm{mM}$ & $32 \pm 3 \quad 23 \pm 4$ \\
\hline
\end{tabular}

*The values are average of three replicates $\pm \mathrm{SE}$. soybean trypsin inhibitor (64\%), and chymostatin (55\%), but low inhibition by inhibitors of pepstatin (38\%), EDTA (23\%), and E-64 (20\%). The results suggested increased dominance of serine proteinases in insect development. The differential susceptibilities of the proteinases to chemical inhibitors observed in the two larval instars suggested the dynamic nature of expression of the gut proteinases possessing different specificity during the course of larval development.

The in vitro stability of pigeonpea PIs against the HaGPs was evaluated by enzyme assays after incubation with 0.02 BApNAase units of HaGP for 30 min (Table 2). In vitro stability of the pigeonpea PIs against HaGPs was reflected by the extent of inhibition after HaGP treatment for $30 \mathrm{~min}$. All accessions of pigeonpea showed inhibition between $60 \%$ to $90 \%$, except in the susceptible pigeonpea cultivar, ICPL 87 (40\%). Inhibition of HaGP was also evaluated at $\mathrm{pH} 7.8$ and $\mathrm{pH} 10.0$ because two groups of proteinases showing activity at specific $\mathrm{pH}$ were observed in the HaGP complement. All accessions of wild relatives of pigeonpea showed high to moderate levels of inhibition at $\mathrm{pH} 7.8$, except in ICPL 87 (42\%). PIs from wild pigeonpeas showed more stability at $\mathrm{pH}$ 7.8 as compared to $\mathrm{pH}$ 10.0. Cultivated pigeonpea exhibited monomorphism in terms of TI and CTI isoforms, contrary to the diverse inhibitory profiles of wild pigeonpeas. Cajanus albicans, C. platycarpus, C. scara- 
Table 5. Trypsin and chymotrypsin inhibitors in wild relatives of pigeonpea against the pod borer, Helicoverpa armigera.

\begin{tabular}{lcccc}
\hline Genotype & $\begin{array}{c}\text { Trypsin } \\
\text { inhibitors }\end{array}$ & $\begin{array}{c}\text { Chymotrypsin } \\
\text { inhibitors }\end{array}$ & TIs + CTIs & Total PIs \\
\hline C. acutifolius & 1 & 2 & 2 & 3 \\
C. albicans & 7 & 5 & 5 & 12 \\
C. cajanifolius & 5 & 4 & 3 & 9 \\
C. lineatus & 4 & 5 & 3 & 9 \\
C. sericeus & 3 & 4 & 3 & 7 \\
C. platycarpus & 6 & 5 & 4 & 11 \\
C. scarabaeoides & 8 & 4 & 3 & 12 \\
C. ferruginea & 6 & 2 & 2 & 8 \\
F. bracteata & 4 & 0 & 0 & 4 \\
F. stricta & 2 & 1 & 1 & 3 \\
P. scariosa & 3 & 4 & 3 & 7 \\
R. bracteata & 5 & 7 & 4 & 12 \\
R. aurea & 6 & 4 & 3 & 10 \\
C. cajan & 7 & 5 & 4 & 12 \\
\hline
\end{tabular}

baeoides, and R. bracteata showed more number of TI and CTI bands. Lowest number of TI and CTI isoforms was observed in C. acutifolius, F. bracteata, and F. stricata (Table 5). Some of the wild relatives exhibited both TI and CTI activities.

Protease inhibitor isoforms of wild relatives of pigeonpea showed significant variation in number, band pattern, and protein specificities towards trypsin, chymotrypsin, and HaGPs as compared to that of the cultivated pigeonpea. Similar observations have been reported in chickpea, where high variation in PIs was recorded in mature seeds of wild relatives than in the cultivated ones [29].

In the present study, it has been observed that PIs from the wild relatives of pigeonpea appeared as HGPIs, indicating that specific PIs from $R$. bracteata, C. albicans and $C$. platycarpus possessed strong inhibitory activity against HGP. However, further studies are necessary to characterize the PIs from wild relatives of pigeonpea to developing strategies for expressing PIs from the wild relatives in the cultivated pigeonpea for resistance to $H$. armigera.

\section{Acknowledgements}

We thank the staff of Entomology, ICRISAT, for their help in maintaining the culture of the pod borer, Helicoverpa armigera, and for raising the wild relatives of pigeonpea in the field for procuring the seeds for evaluation of their proteinase inhibitory activity. We also thank Dr. Md Akbar for reviewing the manuscript, and The
Andhra Pradesh-Netherlands Project on Biotechnology, and the Department of Agriculture and Cooperation, Govt of India, for the funding support.

\section{REFERENCES}

[1] R. Mueller and J. K. P. Weder, "Isolation and Characterization of Two Trypsin-Chymotrypsin Inhibitors from Lentil Seeds (Lens culinaris Medik)," Journal of Food Biochemistry, Vol. 13, No. 1, 1989, pp. 39-63. doi:10.1111/j.1745-4514.1989.tb00384.x

[2] U. Singh and B. O. Eggum, "Factors Affecting the Protein Quality of Pigeonpea Cajanus cajan (L.) Millsp.)," Qual Plantarum/Plant Food for Human Nutrition, Vol. 34, 1984, pp. 251-261.

[3] W. Reed and S. S. Lateef, "The Pigeonpea," CAB International, Wallingford, 1990, pp. 349-374.

[4] H. C. Sharma, "Cotton Bollworm/Legume Pod Borer, Helicoverpa armigera (Hubner) (Noctuidae: Lepidoptera): Biology and Management. Crop Protection Compendium," Commonwealth Agricultural Bureau International, Oxon, 2001.

[5] K. R. Kranthi, D. R. Jadhav, S. Kranthi, R. R. Wanjari, S. S. Ali and D. A. Russell, "Insecticide Resistance in Five Major Insect Pests of Cotton in India," Crop Protection, Vol. 21, No. 6, 2002, pp. 449-460. doi:10.1016/S0261-2194(01)00131-4

[6] H. C. Sharma, "Heliothis/Helicoverpa Management: Emerging Trends and Strategies for Future Research," Oxford and IBH Publishing Co. Pvt. Ltd, New Delhi, 2005.

[7] P. W. C. Green, H. C. Sharma, P. C. Stevenson and M. S. J. Simmonds, "Susceptibility of Pigeonpea and Some of Its Wild Relatives to Predation by Helicoverpa armigera: Implications for Breeding Resistant Cultivars," Australian Journal of Agricultural Research, Vol. 57, No. 7, 2006, pp. 831-836. doi:10.1071/AR05281

[8] H. C. Sharma, G. Sujana and D. Manohar Rao, "Morphological and Chemical Components of Resistance to Pod Borer, Helicoverpa armigera in Wild Relatives of Pigeonpea," Arthropod-Plant Interactions, Vol. 3, No. 3, 2009, pp. 151-161. doi:10.1007/s11829-009-9068-5

[9] G. Sujana, H. C. Sharma and D. Manohar Rao, "Antixenosis and Antibiosis Components of Resistance to Pod Borer, Helicoverpa armigera in Wild Relatives of Pigeonpea," International Journal of Tropical Insect Science, Vol. 28, 2008, pp. 191-200.

[10] L. Jouanin, M. Bonade-Bottino, C. Girard, G. Morrot and M. Giband, "Transgenic Plants for Insect Resistance," Plant Science, Vol. 131, No. 1, 1998, pp. 1-11. doi:10.1016/S0168-9452(97)00239-2

[11] U. Singh, K. C. Jain, R. Jambunathan and D. G. Faris, "Nutritional Qualities of Vegetable Pigeonpea (Cajanus cajan (L.) Millsp.): Mineral and Trace Elements," Journal of Food Science, Vol. 49, No. 2, 1984, pp. 645-646. doi:10.1111/j.1365-2621.1984.tb12489.x

[12] N. P. Chougule, V. K. Hivrale, P. J. Chhabda, A. P. Giri and M. S. Kachole, "Differential Inhibition of Heli- 
coverpa armigera Gut Proteinases by Proteinase Inhibitors of Pigeonpea (Cajanus cajan) and Its Wild Relatives," Phytochemistry, Vol. 64, No. 3, 2003, pp. 181-187. doi:10.1016/S0031-9422(03)00375-3

[13] R. Bressani and L. G. Elias, "The Nutritional Role of Polyphenols in Beans," In: J. H. Hush, Ed., Polyphenols in Cereals and Legumes, St. Louis, 1979, pp. 61-68.

[14] F. Grant, L. J. More, N. H. McKenzie, J. C. Stewart and A. Pusztai, "A Survey of the Nutritional and Hemagglutination Properties of Legume Seeds Generally Available in the UK," British Journal of Nutrition, Vol. 50, No. 2, 1983, pp. 207-214. doi:10.1079/BJN19830090

[15] N. P. Chougule, A. P. Giri, V. K. Hivrale, P. J. Chhabda and M. S. Kachole, "Identification of Amylase Inhibitor Deficient Mutants in Pigeonpea (Cajanus cajan (L.) Millisp.)," Biochemical Genetics, Vol. 42, No. 5-6, 2004, pp. 165-180. doi:10.1023/B:BIGI.0000026632.17713.47

[16] S. A. Godbole, T. G. Krishna and C. R. Bhatia, "Further Characterization of Protease from Pigeonpea (Cajanus cajan (L.) Millsp) Seed," Journal of the Science of Food and Agriculture, Vol. 64, No. 3, 1994, pp. 331-335. doi:10.1002/jsfa.2740640314

[17] E. R. Prasad, A. Dutta-Gupta and K. Padmasree, "Inhibitors from Pigeonpea Active against Lepidopteran Gut Proteinases," Journal of Economic Entomology, Vol. 102, No. 6, 2009, pp. 2343-2349. doi:10.1603/029.102.0641

[18] P. K. Ranjekar, A. Patankar, V. Gupta, R. Bhatanagar, J. Bentur and P. A. Kumar, "Genetic Engineering of Crop Plants for Insect Resistance," Current Science, Vol. 84, 2003, pp. 321-329.

[19] V. D. Parde, H. C. Sharma and M. S. Kachole, "In Vivo Inhibition of Helicoverpa armigera Gut Pro-Proteinase Activation by Non-Host Plant Protease Inhibitors," Journal of Insect Physiology, Vol. 56, No. 9, 2010, pp. 13151324. doi:10.1016/j.jinsphys.2010.04.003

[20] O. H. Lowry, N. J. Rosebrough, A. L. Farr and R. J. Randall, "Protein Measurement with Folin Phenol Reagent," Journal of Biological Chemistry, Vol. 193, 1951, pp. 265-275.

[21] M. M. Pichare and M. S. Kachole, "Detection of Electrophoretically Separated Proteinase Inhibitors Using X-Ray film," Journal of Biochemistry and Biophysical Methods, Vol. 28, No. 3, 1994, pp. 215-224. doi:10.1016/0165-022X(94)90018-3

[22] M. Belew and J. Porath, "Extracellular Proteinase from Penicillium natatum," Methods in Enzymology, Vol. 19, 1970, pp. 576-581. doi:10.1016/0076-6879(70)19045-8

[23] B. F. Erlanger, N. Kokowesky and W. Cohen, "The Preparation and Properties of Two New Chromogenic Substrates of Trypsin," Archives of Biochemistry and Biophysics, Vol. 95, No. 2, 1964, pp. 271-278. doi:10.1016/0003-9861(61)90145-X

[24] S. S. Ambekar, S. C. Patil, A. P. Giri and M. S. Kachole, "Proteinaceous Inhibitors of Trypsin and of Amylases in Developing and Germinating Seeds of Pigeonpea ( $\mathrm{Ca}$ janus cajan (L.) Millsp.)," Journal of the Science of Food and Agriculture, Vol. 72, No. 1, 1996, pp. 57-62.
doi:10.1002/(SICI)1097-0010(199609)72:1<57::AID-JSF $\underline{\mathrm{A} 622>3.0 . \mathrm{CO} ; 2-\mathrm{D}}$

[25] A. P. Giri and M. S. Kachole, "Amylase Inhibitors of Pigeonpea (Cajanus cajan) Seeds," Phytochemistry, Vol. 47, No. 2, 1998, pp. 197-202. doi:10.1016/S0031-9422(97)00570-0

[26] D. P. Bown, H. S. Wilkinson and J. A. Gatehouse, "Differentially Regulated Inhibitor Sensitive and Insensitive Protease Genes from the Phytophagous Pest, Helicoverpa armigera, Are Members of Complex Multigene Families," Insect Biochemistry and Molecular Biology, Vol. 27, No. 7, 1997, pp. 625-638.

doi:10.1016/S0965-1748(97)00043-X

[27] A. P. Giri, A. M. Harsulkar, V. V. Deshpande, M. N. Sainani, V. S. Gupta and P. K. Ranjekar, "Chickpea Defensive Proteinase Inhibitors Can Be Inactivated by Pod Borer Gut Proteinases," Plant Physiology, Vol. 116, No. 1, 1998, pp. 393-401. doi:10.1104/pp.116.1.393

[28] A. M. Harsulkar, A. P. Giri, A. G. Patankar, V. S. Gupta, M. N. Sainani, P. K. Ranjekar and V. V. Deshpande, "Successive Use of Non-Host Plant Proteinase Inhibitors Required for Effective Inhibition of Gut Proteinases and Larval Growth of Helicoverpa armigera," Plant Physiology, Vol. 121, No. 2, 1999, pp. 497-506. doi:10.1104/pp.121.2.497

[29] A. G. Patankar, A. M. Harsulkar, A. P. Giri, V. S. Gupta, M. N. Sainani, P. K. Ranjekar and V. V. Deshpande, "Diversity in Inhibitors of Trypsin and Helicoverpa armigera Gut Proteinases in Chickpea (Cicer arietinum) and Its Wild Relatives," Theoretical and Applied Genetics, Vol. 99, No. 3-4, 1999, pp. 719-726.

[30] A. G. Patankar, A. P. Giri, A. M. Harsulkar, M. N. Sainani, V. V. Deshpande, P. K. Ranjekar and V. S. Gupta, "Complexity in Specificities and Expression of Helicoverpa armigera Gut Proteinases Explains Polyphagous Nature of the Insect Pest," Insect Biochemistry and Molecular Biology, Vol. 31, No. 4-5, 2001, pp. 453-464. doi:10.1016/S0965-1748(00)00150-8

[31] V. D. Parde, H. C. Sharma and M. S. Kachole, "Inhibition of Helicoverpa armigera Gut Pro-Proteinase Activation in Response to Synthetic Protease Inhibitors," Entomologia Experimentalis et Applicata, Vol. 142, No. 2, 2012, pp. 104-113. doi:10.1111/j.1570-7458.2011.01209.x

[32] K. A. Johnston, M. J. Lee, J. A. Gatehouse and J. H. Anstee, "The Partial Purification and Characterization of Serine Protease Activity in Midgut of Larval Helicoverpa armigera," Insect Biochemistry, Vol. 21, No. 4, 1991, pp. 389-397. doi:10.1016/0020-1790(91)90005-Y

[33] J. P. Purcell, J. P. Greenplate and S. R. Douglas, "Examination of Midgut Luminal Proteinase Activities in Six Economically Important Insects," Insect Biochemistry and Molecular Biology, Vol. 22, No. 1, 1992, pp. 41-47. doi:10.1016/0965-1748(92)90098-Y

[34] M. J. Chrispeels and N. V. Raikhel, "Lectins, Lectin Genes, and Their Role in Plant Defense," The Plant Cell, Vol. 3, 1991, pp. 1-9.

[35] W. R. Terra and C. Ferreira, "Insect Digestive Enzymes: Properties, Compartmentalization and Function," Com- 
parative Biochemistry and Physiology, Vol. 109B, 1994, pp. 1-62.

[36] S. Mazumdar-Leighton, C. R. Babu and J. Bennett, "Identification of Novel Serine Proteinase Gene Transcripts in the Midgets of Two Tropical Insect Pests, Scri- pophaga insertulas (Wlk.) and Helicoverpa armigera (Hub.)," Insect Biochemistry and Molecular Biology, Vol. 30, No. 1, 2000, pp. 57-68.

doi:10.1016/S0965-1748(99)00097-1 